\title{
Household's Willingness to Pay for Improved Water Supply Services in Mettu Town: An Assessment
}

\author{
http://doi.org/10.21272/fmir.4(1).86-99.2020
}

S.N. Singh, ORCID: https://orcid.org/0000-0002-1494-4489

Dr, Associate Professor of Economics and Law in the Department of Economics, Faculty of Business and Economics, Mettu University, Mettu, Ethiopia

\begin{abstract}
The purpose of the article is to analyze and determine the willingness of citizens to pay for improving the quality of water services (the income derived from the consumption of water services does not cover the costs of providing such services). The study focuses on Ethiopia's metropolitan areas (including households in town Mettu), as it is the problem of financial scarcity in Ethiopia that is particularly relevant and access to water services is a key component in calculating the human poverty index for most developing countries. Based on a survey of 79 Mettu town households, it is justified that residents view water not as a public good but as an economic good, as they are prepared to pay for it. The survey concluded that an average of $69 \%$ of Mettu households are willing to pay for improved water quality, with household income, water supply satisfaction and supply price having a strong impact on households' willingness to pay for improved water services. In particular, the older the locals are and the higher their income level, the more they are willing to pay for improved water quality and security of water supply. At the same time, rising levels of education in Mettu residents reduce their willingness to incur additional financial costs, more educated people view water services as a boon to the authorities. The results of the study proved that while providing local authorities with high quality water supply services, more than $80 \%$ of households are ready and able to pay for services at a price that exceeds the tariff rate for water supply costs. The article stated that increasing the quality of water supply services by increasing the amount of tariffs for water use will contribute to the growth of financial revenues of local authorities, which will ensure the provision of water supply in the required quantity and on a stable basis.
\end{abstract}

Key words: improved water supply services, willingness, bidding Prices and tariff structure.

JEL Classification: G5, G50.

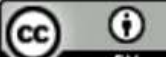

This work is licensed under a Creative Commons Attribution 4.0 International License

Cite as: Singh, S.N. (2020). Household's Willingness to Pay for Improved Water Supply Services in Mettu

Town: An Assessment. Financial Markets, Institutions and Risks, 4(1), 86-99. http://doi.org/10.21272/fmir.4(1).86-99.2020.

(C) The Author, 2020. This article is published with open access at Sumy State University.

\section{Introduction}

\subsection{Backgroud of the Study}

Water is the lifeline of life. And it is contributed to sustain the life, and our general activities of the environment. It is one of the precious gifts to human kind and most basic human needs. Water plays a great role in socio-economic development of human beings and survivals and economic developments. Domestic water supply is one of the fundamental requirements for human life. Without water, life cannot be sustained beyond a few days and the lack of access to adequate water supply leads to the spread of diseases. Women and children bear the greater health burden and drudgery in collection of water and lots of opportunities because of the time that water fetching consumes. Hence the provision of safe and adequate potable water in urban areas in both developed and developing countries is essential for life (World health organization, 2017 Washington D.C).

Access to water services is the major component in the UNDP human poverty index for developing countries. The problem is more heart in developing countries than others. There are many constraints to make potable water easily accessible and it is the problems of the quantity, quality and sustainability. The results are Limited 
modernity, rapid population growth and rapid urbanization. (UNDP 2015, WHO, Millennium Development Goal, 2017).

The main reason for urban water supply, in less developed country like Ethiopia is the absence of adequate finance is the main reason. Most of water supply projects are by their nature requiring huge capitals. The study is an appraisal of the impact of urban expansion on water supply system in Mettu town of Oromia regional state of Ethiopia. In addition, most people's see water as public good that is supplied fairly. It has an impact on the sustainability of the project. In most towns the revenue obtains from consumers do not cover the cost of providing the services (Henok John,2018).

Then it should be implemented cost recovery tax rate at which the revenue gained from the services is fully covered all expenses incurred on water supply. Whether the citizens are able and willing to pay for the services provided is important. This helps to understand the value of the consumer places on the improved water services and for identifying those groups who are not willing to pay and to establish a cost recovery tariff. (Fikadu Megersa June 2016).

\subsection{Statement of the Problem}

Water is crucial for human survival and economic development. Whereas, however, in the list developed countries, actually there are numerous problems. For instance, lack of pure water, technology, equal distribution, etc. However, those problems and obstacles were avoided. The provision of adequate supply of portable water in the urban areas are as developed countries, important to developing countries. For instance, in developing countries the privation of safe and adequate potable water improver health by reducing incidence of water related illness such as diaries, cholera etc. This also help to decrease mortality and morbidity rate and increase GDP by reducing time lost in sic and by making available more health time for individual to participate in labor market. Reducing demand for imported medicine and consumption of healthcare goods, expenditure and there by easing balance of payment problems facing list developed countries like that of Ethiopia (Grossman, Health economics).

The demand for such resources in urban areas of developing countries has been increasing over time under such circumstances pining for efficient and equitable water delivery system in both short and long run crucial to ensure adequate water supply. However, the problem here is the wide spread failure of water supply in the urban areas of Ethiopia which attributed to the cost inquired on water projects is too high. In most urban areas the revenue gained from water supply is unable to cover the cost incurred on it Mattu town is one of the list urban towns in Ethiopia that the revenue gained from water is unable to cover the expense incurred on water services activities. This problem is further aggravated by rapid populations, maters of income such likes of problems, unable to get the required quantity of water at desired time (Fikadu Hk, 2008).

In order to satisfy the rapid growing population water demand as well as the required the quantity required existing population new water project must be assigned as well as the sustainability of existing water project must be maintained. The capital needed to supply water to the town is too high.

This makes the investment on water is difficult. The finance requires to fill this financial problem can be filled by NGO's government and the society itself, but the most sustainable way is cost recovery by the consumer itself to do this the tariff of the town should be at cost of recovery rate. (Griffin entail, 2008).

The main important value of these researches is to examine and to identify such problem of assessing the water supply of the residents in Mettu town. In order to implement cost recovery tariff in urban area of Mettu town by identifying or researching whether the households are able and willingness to pay or not is very important this helps to understand the fundamental value the consumer place on the improved water services. So that prices that reflect the ability and willing to pay of the household for improved water services, as strategy for cost recovery can be established.

In this title, so many researchers lik: Fikadu Megersa June, 2016, Fikadu, Hk, 2008, Griffin, entails, 2008, Henok, John, 2018, UNDP 2015, WHO, Millennium Development Goal, 2017, WHO, 2017,Washington,D.C,2017; Done in the issue of socio-economic (income) and demographic affairs; with exclude the seasonal affairs. Whereas in these all variables, I add season as one factor. That is to test the supply of Mettu town water is the seasonal or not. (My own view, 2011). Meanwhile, after a so long; I recognized, the Mettu town water supply is not depend at seasonal possess. Rather not determined in seasonal mater. That the consequence is the SORE RIVER is the main source to town's water (H2O) supply. 
Financial Markets, Institutions and Risks, Volume 4, Issue 1, 2020

ISSN (online) - 2521-1242 ISSN (print) - 2521-1250

\subsection{Objectives of the Study}

The objectives of the study have two parts:

\subsubsection{The General objective}

The General objectives of this study are to assess the household's willingness to pay for improved water supply services at Mettu town.

\subsubsection{The specific objective}

The specific of objective of the study include:

$>\quad$ To examine the demand for improved water supply.

$>\quad$ To assessing and identify the willingness to pay for water supply.

$>\quad$ To identify and examine the role of households for willingness to pay for improved water supply services.

\subsection{Research Questions}

$>\quad$ What is the demand for improved water supply in Mettu town?

$>\quad$ How to assess the household's willingness to pay for improved water services?

$>\quad$ In what method the household's willingness to pay for improved water supply services assessed?

$>\quad$ What is the role of household for willingness to pay for improved water supply services?

\subsection{Significance of the Study}

The rural and urban poor are the first to suffer of water supply services. A better and much more equitable would be collect water price from consumers and then improved and expand the water supply system.

That is cost recovery is the main requirements for sustainable development in water supply. However, the price of water should be depending on the consumer capacity and willingness to pay for such services. Therefore, this study is important for designed to find it the expenses incurred in supplying in improved water services in urban areas. This implies the study provides required information on the ability and willingness to the person not only to pay for the services but also to sustain their supplies that includes paying for maintenance and investment costs. It would help as a reference material for others who are gonging to conduct their study on the willingness to pay for improved water services in urban areas. While there have been few studies on the subject in Ethiopia. In other setting in relation to this there is a need to prove the relevance of contingent valuation method in Mettu town.

These studies, besides to incur the payment capacity of the town 's societies, should developed the importance of fresh water contributions to the town 's people. For instance, the pure water uses to health sanitation, to avoid disease, to improve the wellbeing to sustain the level of economic growth (GDP), to eliminate the morbidity and mortality. Hence, truly water (especially) improved water is the sources of lief, basis to growth and development, corner to every activity.

\subsection{Scope of the Study}

The scope of the study is restricted to Mettu town due to limited time and financial constraints. Mettu town is selected because of the town has naturally, the source of water is endowed. So, the study is tried to examine and to analysis that, the gift of water is whether necessarily distributed or not. And the study is restricted analyze assessing of willingness to pay and analyze the ability to pay of households only for domestic purposes in the town. The study is also limited to demand side information to water supply problem and on supply side it was including the cost of providing improved water supply only.

\subsection{Limitation of the Study}

When I conduct this study there were some hindrances factors that affect the effectiveness of the study. These factors were lack of deeply aware of experience about how to work the research, involuntariness of respondents in giving adequate information that is necessary for study, lack of enough organized secondary data in the town, and lack of references book in a library. 


\section{Review Literature}

\subsection{Theoretical Literature}

\subsubsection{Concepts and willingness to pay}

The issue that most important for water project designers and planners how to ensure the financial sustainability of a projects. This can involve predicting and estimating what users will be willing and able to pay for purposed water scheme in the future. This is because most water projects in developing countries are financially unsustainable leading to water supply shortages in many places.

Policy makers most of the time sees water supply provision using both demand and supply side. As can be seen from the following chart supply side of water provision usually sees technical alternatives used in water investment. While the demand side of water supply provision sees the households' WTP as the policy recommendation.

WTP is the maximum amount individuals state they are willing to pay for particulars goods or services based on its characteristics (example water supply: the difficult of obtaining, available source, water quality and services level) (Doan Chan, Low paying, 2015).It is the amount a person would be "willing to pay" to obtain a good or services. It is what the person is willing to scarify to get the good. It is the amounts of the money a person can give up receive well and have their utility the same. People are willing to pay very high price for basic minimum water requirements to ensure the survival of households. Consumers are often willing to pay a higher price for water than the tariffs charged. How much higher depends on how much water is being used. WTP diminishes rapidly with no levels of water use, therefore the relationships between WTP and water uses can be shown by a downward sloping demand curve (Sansoon, 2013).

Another definition is one by cardoon and Fonseca and state that "willingness to pay is an expression of the demand for a services and its strong pre-requisite for sustainable cost recovery because it is the materialization of the users' satisfaction and of their desire to contribute its functioning" or Wolde mescal march, 2015).

At this time most of water projects revenue unable to cover the cost incurred on it. So, this willingness to pay survey is an important tool whether to state consumers' preference to pay at cost recovery rate.

\subsubsection{Value of environmental resource}

The term value has many meanings, which may be used in the different used in the different sense. The theory of value in economics attempt to explain the worth of goods and services. Classical economists believed that labor as true measure of value. For them value equals the amount of labor embodied in the community (Srivastava, 1996). The neoclassical economist did not agree with classical concepts of value. They defined value as marginal concept. Jevons, one of the founders of neoclassical economics school defines value as marginal utility. Since then the theory of value developed along this line.

The Neo-classical economists used marginal utility gained by individuals from the last unit consumed to explain the market price of the given community. The neoclassical economists mainly focused on explaining the behavior of price and the allocation of goods and services in the market. They also replaced the classical notions of absolute scarcity with relative's values as determined by the forces of supply and demand (Perm an, et al 2016).

Ideally all values would be expressed in monetary terms. Tradable goods since they have only use values their value can easily expressed in monetary terms. Environmental resource provides a complex set of values, such as life support service, amenity services, material resource to produce goods and services, and used as sink of wastes generated by households and firms.

The value of environmental resources such as improved water consists both use and non-use value. Use value, which can be broken down in to direct and indirect use value arise from the actual uses of environmental resources. The non-uses value or (passive uses) arises from independent uses f resources. Thus, total economic value (TEV) of environmental resource can be cited as the sum of uses and non-use value (Hussein, 2015). As a result of the complexity of environmental resource many environmental resources have no market price. I therefore, require non market valuation techniques to value environmental goods and services. In the following section I would have discussed the non-market valuation techniques. 


\subsubsection{Non-market valuation techniques}

In a market economy goods and services are allocated by the price mechanism. Market price reflects people's willingness to pay for marketable goods and services. However, this approach is difficult for environmental resources, for market failures often occur in providing environmental resource due to externalities. Many environmental resources are not traded in markets. The market rarely exists for environmental goods and services (Pearce, et al, 2017, page 6)

I therefore, require non-market valuation method to value improvement and/or reduction in environments goods and services including water resources. "Although water is increasingly allocation by market mechanism their units attributed make it a classical example of the markets potential failure to achieve an economically efficient allocation. Externalities, public goods decrease costs in supply and higher transaction costs among reasons why market will not always best serve society in allocation water resources. "Thus, I would use the nonmarket valuation techniques to provide measures of value and scarcity for economic policy making to water" (Young, 2017).

Economists have developed the broad categories of non-market valuation techniques for valuing the value of public environmental resource. These valuation techniques are called revealed preference and stated preference methods. Cross cutting methods, which combines market based and non-market valuation techniques such as benefit transfer and unit day methods also use for value public environmental goods, such as water resources. The most widely recognized revealed preferences and the stated preference valuation technique are discussed below:

\subsubsection{Revealed Preferences methods}

The revealed preference methods infer the value of environmental goods by studying their actual or revealed behavior in closely related market through the application of some models of relationship between marketable goods and environmental services. The great advantage of the revealed preference methods is that its dependence on the actual behavior (Bock steal et al page 2005).

However, the application of revealed preference methods requires weak complementarities between environmental goods and private goods, the revealed preference methods have also some drawbacks. It is used to value only use values. The method is not appropriate for valuing nonuse values of environmental goods. The other problems in applying these methods are that it is often difficult to find suitable and reliable links between market goods and environmental amenities. The sensitivity of the evaluation results with respect to assumption of models is also another drawback of the revealed preference methods. The revealed preference methods are used in relation to water resources and the hedonic pricing method, the traveled cost method and defensive or averting (John, 2016).

\subsection{Hedonic Pricing method}

The Hedonic pricing method is one of the revealed preference non-market valuation techniques. It is derived from the characteristics theory of value and seeks to explain the value of commodities as a bundle of valuable characteristics. The method indirectly measures people's willingness to pay for change in water supply. The Hedonic pricing method for it is based on actual market pricing its application is straight forward and uncontroversial (Young 2017, page 256).

The main short coming of the method is that it requires real property markets and does not capture nonuse values of environmental resource (Bock steal, et al page 558-563).

\subsection{Travel Cost Method}

Travel cost method is originated with letter sent to the USA national park by Harold Hosteling. It the oldest environmental valuation technique and is used to assess the value people places on recreational activities such as parks, lakes and other areas which host a good deal of recreational activities.

The travel cost method assessing the demand function of recreational sites and the sites' consumer surplus. The sites' consumer surplus found by this way, however, is only use value. It does not include nonuse values. The method failed to assess non-use values. The other drawback of the method is that its application is limited only for valuation of recreational sites (Seller Christine, et al 2013). 


\subsection{Defensive (averting) behavior}

This method is less frequently used valuation techniques. The method is used to infer value from household expenditure to avert environmental problems, such as water pollution. The methods are used to measures people willingness to pay for welfare gained from the improved environmental resource such as from clean water. The general premise of the method is that a rational person will adopt defensive or averting behavior as long as the value of damage avoided is greater than aversive expenditure. The method is used for valuation of water quality improvement to protects against polluted drinking water (Young, 2015, page 133, Hussen, 2017, page 298)

\subsection{Empirical Literature}

Most Empirical studies on willingness to pay for improved water resources and supply indicate that there is effect income, household size, education and from existing water resources that influence WTP for improved water resources. For example, in 2004, Pan Kahn Nam and Transom Hung Son did a study on household demand for improved water services on Ho Chi Minh city, Vietnam. The study assumes the willingness of people in Ho Minh city to pay for improvement in their water supply system.

It also investigates what aspects of water supply, such as quality and water pressure are most important. Many households surveyed already had to do a lot and spend lot of money to cope with unreliable poor-quality public water supply they current use. The study found that people are on average WTP between VND 148000 and VND 175000 for improvements in their water supply. Also, households without piped water are more WTP for improved services than those that already enjoyed fixed supply. Non-piped households place more importance on water quality than water pressure. The studies have all employed CVM to solicit WTP for improvement of water supply. In recent years CVM has been extensively applied to variety of water related issues in different frame works. Some of the CVM studies done in improved water supply services are cited below.

Non-piped households place more importance on water quality than water pressure. The studies have all employed CVM to solicit WTP for improvement of water supply. In recent years C VM has been extensively applied to variety of water related issues in different frame works. Some the CVM studies done in improved water supply services are cited below. Briscoe et al (2014) employed CVM to assess household's WTP for improved water supply in three rural areas of Brazil; one relatively prosperous well-watered southern state of panama and the two dry areas of the northern areas. The finding of the study also indicates that it is possible to improve free water to the poor at public taps without harming the financial viability of the scheme. Whittington et al (2014) carried out a CVM study to assess household's willingness to pay for drinking water in Onitsha, Nigeria. The authors used a bidding game to elicit households' WTP for improved drinking water. In this study 235 sample households were interviewed in person to elicit households' WTP for improved water services. The findings for this study WTP for improved public water system. This study also indicates that if the improved public water system constructed water services can be provided to the people at lower prices below Private Vendor's price and social welfare would be increased.

WTP for the improved water services In Ethiopia we found some studies done on improved water supply through CVM method. Fesseha Abera (2016) employed CVM to evaluate the households WTP for improved water service supply in Meki town. Assefa Chaka (2017) used the CVM to assess the WTP for improved water supply in Addis Ababa by taking four kebeles as a case study. According to the finding of this research female respondents had more willing to pay for improved water service as compared to male respondents. Genanew Bekele in his study used the midpoint of WTP interval in the bidding game with in which the respondents' WTP. As his study were socio-economic and demographic factors. The findings of the study show that the entire surveyed households preferred the provision of the improved water service. The survey households show their WTP about 15 times more than the existing tariff if they get improved water service.

\section{Methodology of the Study}

\subsection{Description of the study}

The study would be conducted in Mettu town which is located in the northern part of Ethiopia in Oromia regional state in Mettu town at a distance of $898 \mathrm{~km}$ from capital city of Addis Ababa and $118 \mathrm{~km}$ from regional capital city of Mekele. 


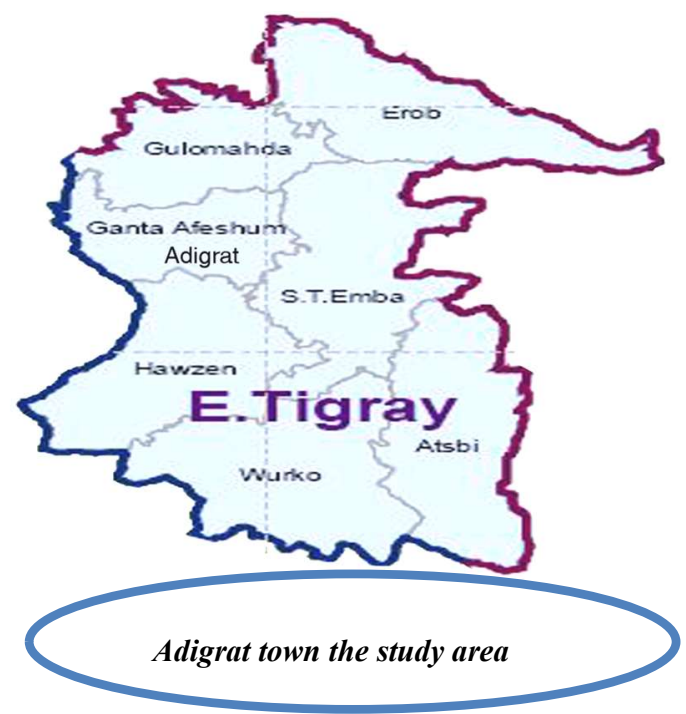

Figure 1. The description map of Mettu town

Mettu town is located in Misreqawi (Eastern) zone at longitude and latitude $14{ }^{\circ} 16^{\prime} \mathrm{N}$ and $39^{\circ} 27^{\prime} \mathrm{E}$ with an elevation of $2457 \mathrm{~m}$ above sea level and she located south of the border of Eritrea. The population of the town is $76,400(2013)$, with the area of $7.247 \mathrm{mi}^{2}$ and the elevation of 8,061 '.

Adigrat is the last important Ethiopian city south of the border with Eritrea, and is considered to be a strategically important gateway to Eritrea and the Red Sea. Adigrat was part of Ganta Afeshum woreda before a separate woreda was created for the city.

\subsection{Data type and source}

To undertake these researches, the study mainly uses primary and secondary data would be used during the data were collected. The primary data would be collected from local peoples and towns and the concerned offices. The secondary data would be collected from recorded and previous works of services provides and other related studies in the subjects.

\subsection{Sample design and size}

The study population was all the domestic water uses of households in Mettu town. In order to the represent the population with sufficient accuracy and enters the sample results to the population the target sample households were selected using a two-stage simple random sample technique.

In the first stage 2 kebeles (sefers) or quarters were randomly selected out of three (3) kebeles' (sefers) found in the town these members of kebeles were considered to be sufficiently large for drawing valid statistical influence and were also manageable to be surveyed with the available resource of finance and time. From the total population of Adigrat town is 76400 . Out of this total population 79 sample of household's were selected randomly from kebeles' (sefers) using proportional size sample technique.

\subsection{Method of data collection}

For collecting the data suitable technique would be used depending up on the nature of the data. Primary data would be collected from households through questionnaires and key informal view of interview.

The questionnaires that are used to elicit household's willingness to pay for improved water supply services can be divided in to three basic parts:

Firstly, Household socio-economic characteristics secondly, existing water supply situations of the town and thirdly, household willingness to pay for improved water supply questions.

For secondary data related are going to be consulted and reviewed.

\subsection{Method of data analysis}

After the relevant data are gathered descriptive analysis method were used. The main reason to use descriptive analysis is most of the data collected through open-ended questionnaires and interviews which is difficult to 
quantify. Hence it is appropriate and convenience to use the technique based on the facts and information collected. This descriptive data analysis can analyze by tables, graph, and figures.

\section{Results and Discussion}

\subsection{Socio Economic characteristics of respondents}

Using a contingent valuation survey, a total of 79 sample households were interviewed during a survey. From the total sample households, 43(47.05\%) are male households, while the remaining 36(52.94\%) are female households. The results also showed that 39.82 year is the average age, with minimum of 18 years and maximum of 85 years.

The educational level of the respondent showed that, majority of the respondents was not able to read and write (illiterate), while the maximum level is master's degree. From the respondents who gave answer to this questions, $12(14.17 \%)$ can neither read nor write (illiterate), $26(30.59 \%)$ have with in primary education (1-8 grades), 25(29.41\%) have within secondary education (9-12 grades), diploma 12(14.12\%), Degree 8(9.14\%) and the remaining $2(2.35 \%)$ were above degree. The average family size of the total sample households was 4.12 the maximum family size of the sampled households is 10 , while the minimum of 1 . The data about the occupation of the respondents shows that $40(47.05 \%)$ of them were self-employed, $18(21.17 \%)$ of them were government worker, while the remaining $27(35.14 \%)$ were unemployed.

The average monthly income of the sample households was Birr 1262.77, which is ranging from the maximum of Birr 10,000 to the minimum of Birr 0. Data about the income of households reveals that, there is income disparity between the households of the town.

Attempt was also made to know the wealth status of the sampled household. Based on this, from total sample households of 36(42.35\%) of them reveals that they live in their own house, 49(57.64\%) live in privately rented house.

Households were given different social services to rank them in accordance with their priority of need. Survey results showed that $71(20 \%)$ rank water service as their first need, $9(10.58 \%)$ rank health service as their first need, 5(5.88\%) rank electric service as their first need.

Regarding their second and third choice, most of the respondent chooses health and electric service respectively. From this we are clearly understood water supply is the priority need of sample households and the most important thing for them.

\subsection{Existing water supply situation}

Household's attitude towards current water supply situation of the town is presented in the following section by discussing main source of water, existing price of water, quantity, quality and reliability of current water supply source.

\subsubsection{Current source of water supply}

Household's attitude towards current water supply situation of the town is presented in the following section by discussing main source of water, existing price of water, quantity, quality and reliability of current water supply source.

Table 1 Current source of water supply for the town

\begin{tabular}{|l|c|c|}
\hline \multicolumn{1}{|c|}{ Source of water supply } & No of respondents & Percentage \\
\hline Private piped & 62 & $72.94 \%$ \\
\hline Public tap & 23 & $27.05 \%$ \\
\hline Total & 85 & $100 \% ?$ \\
\hline
\end{tabular}

Source: household survey, 2016. 


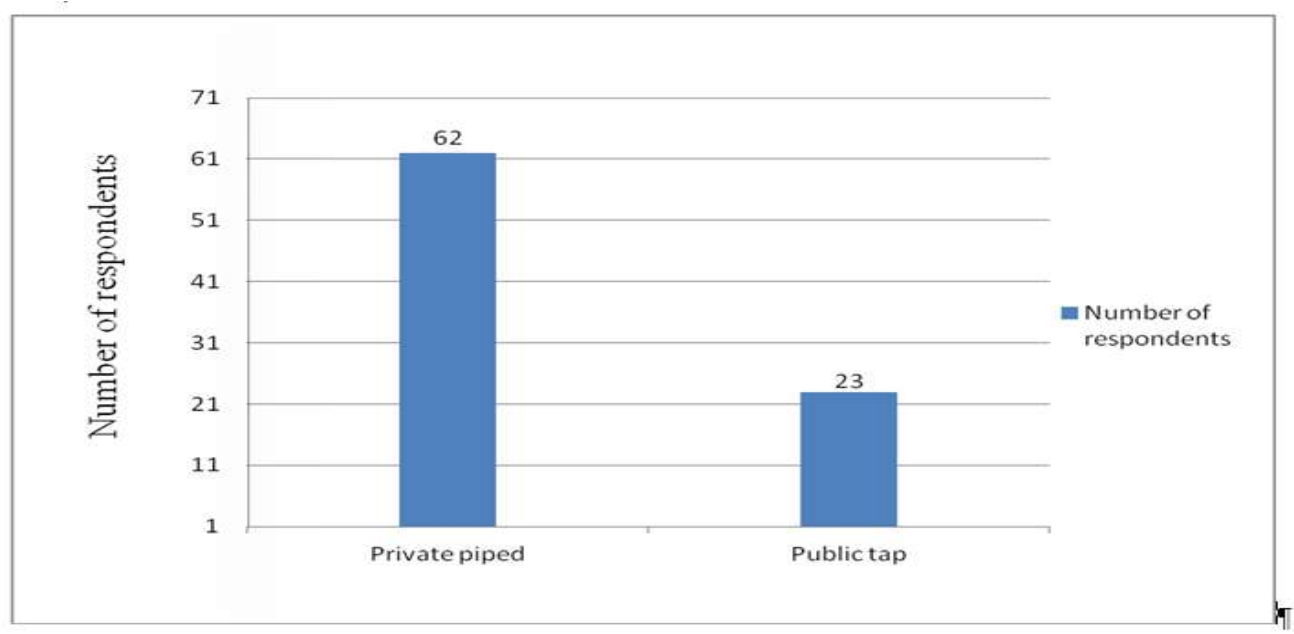

Figure 2. Current source of water supply

Source: own survey, 2016.

Based on this most of them said that the house has not their own and they do not need piped water source.

\subsubsection{Current price of water}

Survey about the current government water tariff of the town's water supply is based on a progressive water tariff calculation aiming to support the majority low income customer and high consumers to pay progressively higher as their consumption. Total payment is calculated after each consumption category identified from the total; consumption and multiplied by their respective prices, then each consumption in birr for each category is summed up to be added with the meter rent depending on meter size.

Table 2: consumption category of Mettu town water supply system

\begin{tabular}{|l|c|l|}
\hline $1^{\text {st }}$ category & From $0-3 \mathrm{~m}^{3}$ & 4.00 birr \\
\hline $2^{\text {nd }}$ category & From $3.1-6 \mathrm{~m}^{3}$ & 4.25 birr \\
\hline $3^{\text {rd }}$ category & From $6.1-10 \mathrm{~m}^{3}$ & 4.50 birr \\
\hline $4^{\text {th }}$ category & From $10.1-15 \mathrm{~m}^{3}$ & 4.75 birr \\
\hline $5^{\text {th }}$ category & From $15.1-25 \mathrm{~m}^{3}$ & 5.00 birr \\
\hline $6^{\text {th }}$ category & From $25.1-40 \mathrm{~m}^{3}$ & 5.25 birr \\
\hline $7^{\text {th }}$ category & From $40.1-100 \mathrm{~m}^{3}$ & 5.50 birr \\
\hline $8^{\text {th }}$ category & $>100 \mathrm{~m}^{3}$ & 5.75 birr \\
\hline
\end{tabular}

Source: household survey, 2016.

Meter rent by size (birr): ${ }^{1} / 2^{\prime \prime}=3$ birr, ${ }^{3} / 4=4$ birr, $1 "=10$ birr, $1^{1 / 2}{ }^{\prime \prime}=15$ birr, $2 "=25$ birr and $2^{1 / 2}{ }^{\prime \prime}=40$ birr

From sample collected data households who have piped water supply source can consume on average 81.08 litter of water per month. However, households are not using the required quantity of water at desired time. This refers to there is a high scarcity of water in both the geographical composition and the supply of water in Mettu town. But when I would request the selected sample household, they were highly desired to pay for improved water services based on the existing tariff rate.

\subsubsection{Reliability of current water supply source}

Contingent valuation survey about quantity, quality and reliability of current piped water supply source indicated that, most of respondents said that the quality of water is good but there is a problem in all time availability of water supply service. That means there is minimum quantity supply of water what the household of the town needed.

Regarding the quantity of water supplied to town's all the population said that quantity of water delivered at a time is poor. The most of sample households responded that they need improved water supply. Their main reason for demanding improved water supply is, there is no enough water at the required quantity in the desired time. 
But the office of Mettu town water services and sewerage said that it is a problem of water but after the current project of water construction is finished this problem will be solved. In order to cover the cost recovery tariff of the water supply of the town. A question related to the quality of water was, whether the households uses any purification method before they drink or not. $97.3 \%$ of households who were responding for this question were not using any purification method before drinking and using for domestic use. And the remaining $2.7 \%$ of respondents were using cleaning materials such as boiling, and who agar before using the water.

Those who were not using any purification method were asked why they are not, based on this $66.66 \%$ of households said water is clean for drinking and domestic use, $11.1 \%$ purification is costly and time consuming, and the rest $22.22 \%$ responded water is not clean but no side effect on health. This data was referring to as the existing water supply is cleaned. With regard all time availability of water, only a small proportion of respondents were said the water availability at all time is good. While most of the respondents responded availability of water at all time is poor. On average water is available only for three days per week.

\subsubsection{Level of satisfaction with existing source}

Data about the level of satisfaction with the existing source of piped and public tap water supply indicate that, most of the respondents are not satisfied with the existing source. Because there is no equilibrium between the supply of water and the residents demand. The reason for dissatisfaction with the existing source is the quantity of water supply per day is not enough and it is not found at desired time.

\subsubsection{Diseases episodes}

Water quality and diseases episodes are directly related. As the water quality becomes good, the chance of getting water borne diseases such as typhoid, diarrhea and vomiting is getting lower. This question was forwarded to sampled household Mettu town. From sample households who were responded to this question, $17.3 \%$ were said that one member of their family over 12 years in the last one year were affected with one the above diseases. This indicated that Out of 10 family 2-3 members of family there is a chance be affected by this disease. This is a source of scarce supply of water on be sides of minimizing the diseases.

\section{3 demand and willingness to pay for improved water supply}

In the previous two parts, data about household's attitude towards current water supply situation is presented together with their socio-economic and demographic characteristics. In this section, household's willingness to pay for improved water supply service is presented. Before during that, it is important to the question presented to the sample households. The provision of improved water service among other things means, good quality of water which is save for health and increased amount of water available for use.

It also means a high reliable source at any time (7 days a week, 24 hours a day). Now, let as assume that you have option for a private connection to such an improved piped water supply scheme. The improved system will provide with as much as water as you wish at any time of the day, throughout the year. Let as also assume that you will be charged a monthly water fee based on the volume of water your household consume in a month (the tariff is progressive), the more you consume the higher will be your monthly bill. The tariff per volume will be the same for all consumes. You may not then be required to pay initially the costs of connection to the new scheme. Instead, it will be distributed over several years in your monthly bill (the payment will be builtin the monthly water bill). You are required to pay a minimum of at cost recovery after the improved water supply has been come into effect.

\subsubsection{Demand for improved water supply}

Provision of improved water supply as much important among them it is reducing the incidence of water born diseases such as diarrhea; it also improved sanitation activities, and generally contributes to the economic growth of every nation. Regarding the choice for the above improved water supply, since most of household are not satisfied with the existing source, the told they need improved water supply. Source: household survey. The most of sample households responded that they need improved water supply. Their main reason for demanding improved water supply is, there is not enough water at the required quantity in the desired time.

\subsubsection{Willingness to pay (WTP) for improved water service}

The first question related willingness to pay for improved water supply is, whether they are willing to participate in improving water supply service. The answers from respondents reveal that, if the town's water supply office provides them the above improved water supply option, most of the sample households 
$69(67.03 \%)$ responded they are willing to pay at a cost recovery tariff rate. While the remaining $16(32.97 \%)$ is not willing to pay for the improved water supply option provided to them at a cost recovery tariff rate.

Graph: 2 household willingness to pay for improved water service

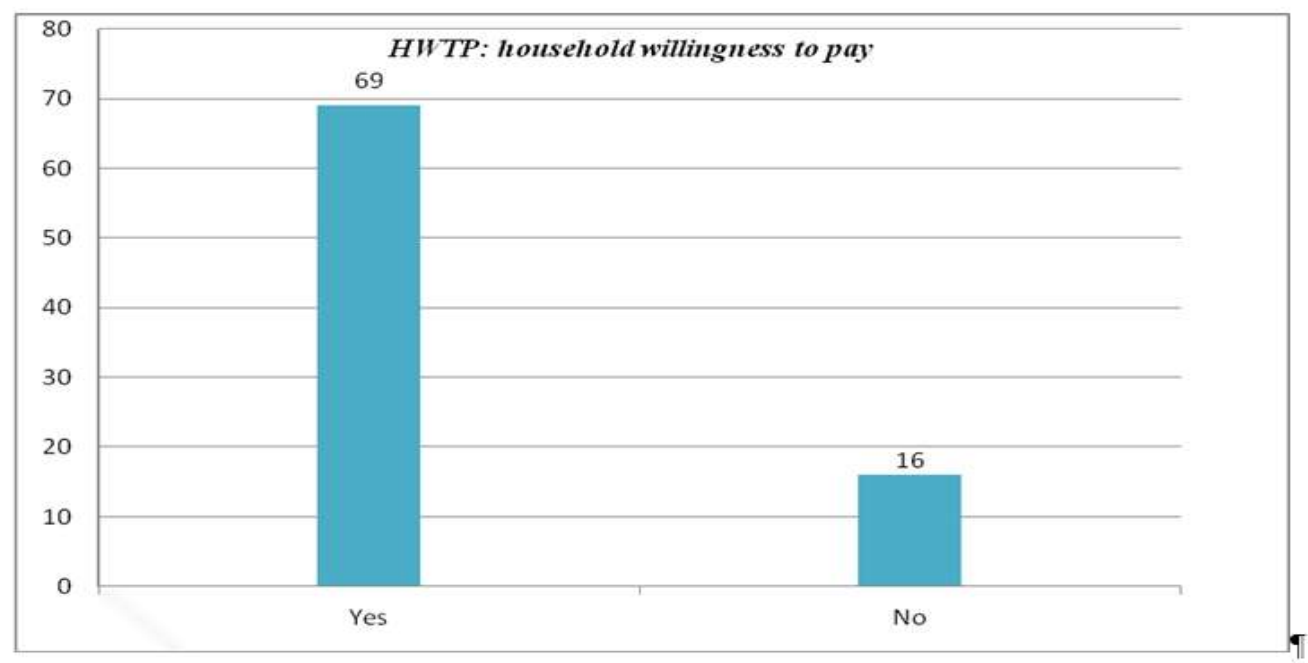

Figure 3. Household willingness to pay for improved water service

Source: Own survey from household, 2016.

Responses from the economic valuation question of mean WTP reveal that, the mean willingness to pay for the improved water supply services of the sampled households were 16.32 cents per bucket for water. This implies that the resident of the town is willing to pay more than the existing tariff rate. The frequency distribution for willingness to pay responses indicate in the following table that from the total of 79 sample households, 28(32.94\%) are willing to pay between 0.00-5.00 cents per bucket of improved water.

Table 3. Household response of WTP for improved water supply

\begin{tabular}{|l|l|l|}
\hline WTP & Freq & percent \\
\hline No & 16 & 18.82 \\
\hline Yes & 69 & 81.17 \\
\hline Total & 85 & 100.00 \\
\hline
\end{tabular}

Source: own survey, 2016.

$21(24.7 \%)$ of sample household's fare willing to pay between 5.01-10.00 cents, $20(23.52 \%)$ of them are willing to pay between 10.01-20.00 cents and $16(18.82 \%)$ are willing to pay between 20-30 cents per bucket of water. From the table it is also clear indicated that more than $75 \%$ of sample households will be willing to pay between $0-20$ cents. This indicated that minimum of price was got by high price of water but high amount of water was got by minimum price because, when there is high amount of water is supplied the household demand of water is stabilized.

Out of the total sample $81.17 \%$ were accepted to improve willingness to pay water supply of the town. And the remaining $18.82 \%$ were not accepting to willingness to pay. Because of some individuals have minimum of income per day and some of them were depend on their family.

Table 4. Frequency of WTP ranges

\begin{tabular}{|l|c|c|}
\hline Household bid & Frequency & Percentage \\
\hline 0.05 & 19 & 22.35 \\
\hline 0.1 & 21 & 24.70 \\
\hline 0.2 & 22 & 25.88 \\
\hline 0.3 & 23 & 27.07 \\
\hline Total & 85 & 100 \\
\hline
\end{tabular}

Source: household survey, 2016. 


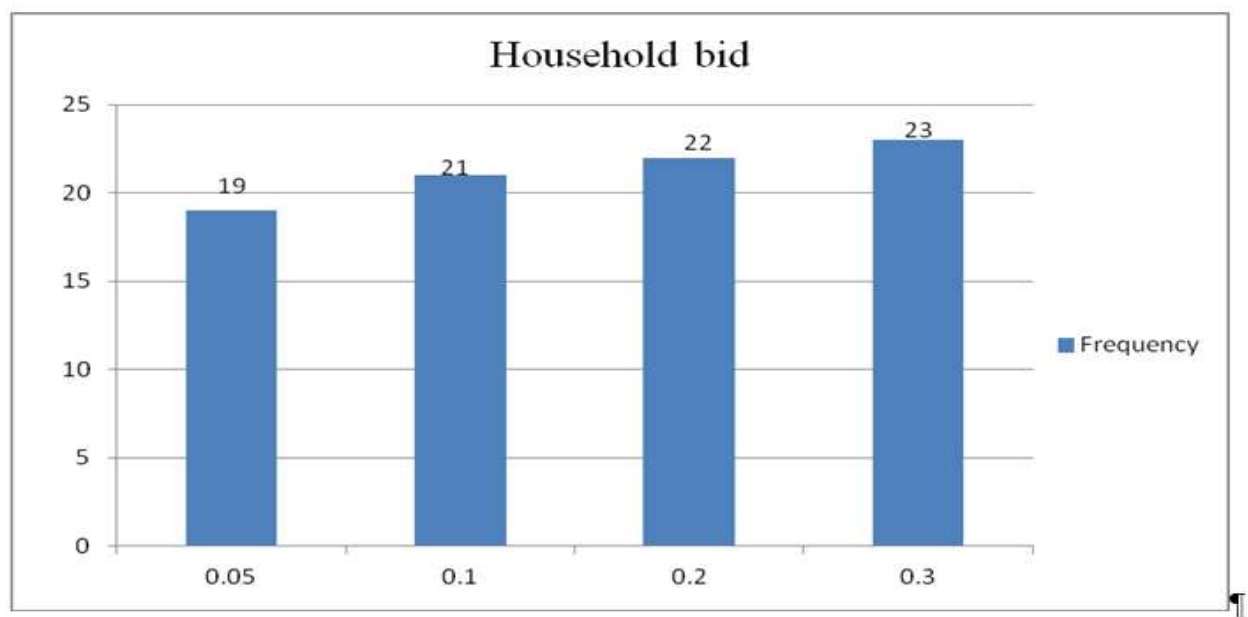

Figure 4. Household bid.

Source: own survey, 2016.

From the collected data household bid were highly determined to assess the individual's willingness to pay for improved water supply services. When household's income increases the household demand to bid for improved water supply of the town were increases. From the collected data the frequency of willingness to pay ranges on household bid is more affect the price of water. a higher income was willing to pay for an improved water quality and reliability of supply. This finding corroborates the environmental economic theory which assumes that the demand for an improved environmental quality increases with income.

\section{Conclusion and Recommendation}

\subsection{Conclusion}

This paper examined the WTP for an improved water quality and reliability in Mettu town. In this study the demand side of the improved water supply services was analyzed. The survey responses of 79 randomly selected household from all the three (3) kebeles of Mettu town were analyzed in the study. The study's findings can be summarized as follows. First, on average, $69 \%$ percent of the households in Mettu town are willing to pay for improved water quality. Second, in Mettu town those with a higher income were willing to pay for an improved water quality and reliability of supply. This finding collaborates the environmental economic theory which assumes that the demand for an improved environmental quality increases with income. Third, the older person the more they are willing to pay for improved water quality and reliability in Mettu town. The suggest that Mettu town residents in general regard water as an economic good as they are willing to pay for its provision, as opposed to a public good. Lastly, in Mettu town educated people are lesser willing to pay for improved water quality and reliability. This might be suggesting that they regard water services as an entitlement that should be provided by the government.

The sampled households were asked question related to their socio-economic and demographic characteristics, water use practice, and problems with existing water services system and some general questions. Most of the respondent chooses water, health and electric service respectively in ordering the services in their life. Good quality water is vital for health and improvement of the well-being of human beings. If the piped water distribution does not provide good quality water continuously, concerned and private agents might intervene. From this we are clearly understood water supply is the priority need of sample households and the most important thing for them. Regarding the quantity of water supplied to town's all the population said that quantity of water delivered at a time is poor. But the office of Mettu town water services and sewarage said that it is a problem of water but after the current project of water consraction is finished this problem will be solved. In order to cover the cost recovery tarrif of the water supply of the town

A question related to the quality of water was, whether the households uses any purification method before they drink or not. $97.3 \%$ of households who were responding for this question were not using any purification method before drinking and using for domestic use. Water quality and diseases episodes are directly related. As the water quality becomes good, the chance of getting water borne diseases such as typhoid, diarrhea and vomiting is getting lower. This question was forwarded to sampled household Mettu town. Responses from the economic valuation question of mean WTP reveal that, the mean willingness to pay for the improved water 
supply services of the sampled households were 16.32 cents per bucket for water. This implies that the resident of the town is willing to pay more than the existing tariff rate.

The most of sample households responded that they need improved water supply. Their main reason for demanding improved water supply is, there is not enough water at the required quantity in the desired time.

\subsection{Recommendation}

Mettu town suffers from increasing problem of water shortage. The inhabitants of the town have high eager to have reliable and improved water service. All the surveyed households expressed their willingness to pay for improved water services above the existing tariff structures. Those, the expected revenue from the provision of the improved water services will be high. The findings of this study also clearly show socio-economic and demographic characteristics and water related that affect household's willingness to pay for the improved water services.

\section{Based on research findings, the following are policy recommendations:}

$>\quad$ The surveyed sampled households expressed their interest to pay above existing tariff structure. Thus, if the improved water supply is provided to the town by increasing water tariff structure the financial viability of the authorities will be improved and at the same time the water needed of the households will be satisfied.

There is no fair distribution of water supply in Mettu town therefore; I recommend that the concerned office should be fairly distributing the existing water services.

The current construction of water supply and the demand of household is not balanced so, Mettu water supply offices and sewerage should be constructed another project to prove such a problem when household is desired to pay above the existing price of water. This is very important in the economic growth of Ethiopia. As the demand of basic need of households fulfilis the sustainable development will be fulfilled.

Government of Ethiopia should intervene to prove such a problem as Mettu and other area of Oromia region which haven't access water in nature and NGOs should construct project to sustain our economy for increasing high human labor and skilled manpower.

\section{References}

1. Ahtiainen, H. (2007). The willingness to pay for reducing the harm from future oil spills in the Gulf of Finland: an application of the contingent valuation method. (Discussion papers / Department of Economics and Management, University of Helsinki; 18). Available at: https://www.researchgate.net/publication/2 67261222 Willingness to pay for_improvements in the oil_spill_response capacity in the_Gulf_of_Finl and_-an_application_of the contingent valuation_method

2. Alebel, B. (2004). Estimating households' affordability and willingness to pay for improved water supply services in urban areas, using contingent valuation method (M.Sc. Thesis, Department of Economics, AAU.) Available at: http://etd.aau.edu.et/bitstream/handle/123456789/11452/34.pdf? sequence=1\&isAllowed=y

3. Economic Planning Unit. (2009). Incidence of poverty, by ethnicity, strata and state, Malaysia 19702009. Household income and poverty. Available at: https://www.mea.gov.my/ms/c/document $\% 20$ library\%20/get file?uuid $=5$ bf3a7ca37a7-4ebb-96c6-\%20634ce17141dc\&groupId $=34492$

4. Fikadu Megersa (2011). Assessing households' willingness to pay for improved water services. Water supply services in Holeta town using contingent valuation method. Addis Ababa. Available at: http://etd.aau.edu.et/bitstream/handle/123456789/11452/34.pdf? sequence=1\&isAllowed=y

5. Genanaw, B. (1999). Analysis of Determinants of Household's WTP and Demand for Improved Water Services: A Contingent Valuation Study in Harar Town, Ethiopia. (M.Sc. thesis, Department of Economics, AAU.) Available at: http://etd.aau.edu.et/bitstream/handle/123456789/11452/34. pdf?sequence=1\&isAllowed =y

6. Hartono, D. (2007). Analysis of Willingness to pay and determinants of drinking water and sanitation availability In Indonesia: using Hedonic price model approach and logistic model. Band ung, Indonesia: padjardian University, Economics department. Available at: https://ideas.repec.org/p/ unp/wpaper/ 200712.html 
7. Kamaludin, M., Rahim, K.A. (2013). Assessing Consumer's Willingness to Pay for Improved Domestic Water Services in Kelantan, Malaysia, The International Journal of Social Science, 8(1), ISSN 23054557. Available at: https://www.tijoss.com/8th\%20Volume/mahirah.pdf

8. Leggett, C.G., Bockstael, N.E. (2000). Evidence of the Effect $s$ of Water Quali ty on Residential Land Prices, Journal of Environmental Economics and Management, university of Ohio USA. Available at: https://econpapers.repec.org/article/eeejeeman/v_3a39_3ay_3a2000_3ai 3a2 3ap_3a121$\underline{144 . h t m}$

9. Leggett, Christopher G., and Nancy E. Bockstael. (2000). Evidence of the Effect s of Water Quali ty on Residential Land Prices, Journal of Environmental Economics and Management, University of Ohio USA. Available at: https://pdfs.semanticscholar.org/dd24/597ea883cd7145055f2016712e806fa7b986.pdf

10. Mehrara, M., Pakdin, J and Neja, A. (2009). Willingness to Pay for Drinking Water. ISSN: 2201-6333 (Print) ISSN: 2201-6740 (Online) www.ijern.com. 14 Connections: The Case of Larestan, Iran; Journal of Academic Research in Economics;1(2); 191-203. Available at: https://ideas.repec.org /a/shc/ jaresh/v1y2009i2p183-194.html

11. Whittington, R., Eero, V. (2012). Strategy-as-Practice: Taking Social Practices Seriously, The Academy of Management Annals, 6(1):1-52. DOI: https://www.10.1080/19416520.2012.672039

12. Woldemeskel, B. (2006). Evaluation of water supply systems in selected urban poor areas of Addis Ababa, Ethiopia. Netherlands: UN ESCO-Institute of water education. Available at: https://ihedelftrepository.contentdm. oclc.org/digital/collection/masters1/id/257208/

13. World Bank Water Demand Research Team (1993). The demand for water in rural areas: determinants and policy implications. The World Bank Research Observer. 8(1), 47-70. Available at: http://documents.worldbank.org/curated/en/537201468739280756/The-demand-for-water-in-rural-areasdeterminants-and-policy-implications

14. World health organization. (2003). Domestic water quality, service level and: Geneva, Switzerland: World Health Organization (WHO) documents production services. Available at: https://www.who.int/water_sanitation_health/diseases/WSH03.02.pdf 